\title{
PERFORMANCE OF A GRID CONNECTED RESIDENTIAL PHOTOVOLTAIC SYSTEM WITH ENERGY STORAGE
}

\author{
G. Ernest Palomino, SRP, Phoenix, AZ \\ John Wiles, Southwest Technology Development Institute, Las Cruces, NM \\ John Stevens, Sandia National Laboratories, Albuquerque, NM \\ Frank Goodman, EPRI, Palo Alto, CA
}

\begin{abstract}
In 1995, Salt River Project (SRP), a public power utility located in Phoenix, Arizona, collaborated with the Electric Power Research Institute (EPRI) and Sandia National Laboratories (Sandia) to initiate a research project to evaluate the feasibility of using a photovoltaic (PV) power system with battery energy storage to match PV output with residential customer peak energy demand periods. The PV power system, a $2.4 \mathrm{~kW}$ PV array with $25.2 \mathrm{kWh}$ of energy storage, was designed and installed by Southwest Technology Development Institute (SWTDI) at an SRP-owned facility, known as the Chandler Research House during August 1995. This paper presents an overview of the system design, operation and performance.
\end{abstract}

\section{INTRODUCTION}

Photovoltaic (PV) power systems offer electric utilities an opportunity to meet part of the daily energy requirements of the residential customer with a renewable energy source - the sun. Unfortunately, for SRP and many other utilities, the production profile of a PV power system does not match the peak daily energy demand of the typical residential customer. For SRP, the peak load period during the summer season occurs between 4 PM and 7 PM while during the winter season, the peak load demand occurs between $6 \mathrm{AM}$ and $10 \mathrm{AM}$. The peak production from a PV power system occurs between $10 \mathrm{AM}$ and $2 \mathrm{PM}$. Given this mismatch between PV generation and peak demand, SRP in collaboration with the Electric Power Research Institute (EPRI) and Sandia, initiated a research project to evaluate the operating and performance characteristics of a PV power system with energy storage [1].

The primary project objective was the demonstration of a PV power system that allowed for the storage of solar energy and for the dispatch of that energy during the customer's or utility's peak demand
This work sponsored in part by the US Department of Energy under contract DC-AC04-94AL85000

period. A secondary objective was to examine the effect of the system's operation on the annual bill of a typical residential customer. To accomplish this, a grid-connected PV power system with battery energy storage was installed at SRP's Chandler Research House during August 1995.

\section{BACKGROUND}

SRP, an Arizona based public power utility, provides electric energy services to over 600,000 customers in the Phoenix metropolitan area. This is an area of the US desert southwest with an excellent solar resource. It is characterized by generally clear days and an average daily solar irradiation of $6-7 \mathrm{kWh}$ per square meter. Because of these characteristics, SRP has conducted numerous research and development projects in the renewable energy technology areas, including photovoltaics. SRP has had an interest in determining the feasibility of using battery storage coupled with a PV system to match the PV production with the peak load periods. Thus, SRP, in collaboration with EPRI and Sandia retained Southwest Technology Development Institute (SWTDI), affiliated with New Mexico State University, to design, install and start up a PV power system with energy storage at the Chandler Research House (located at 1123 West Barrow in Chandler, Arizona). The system was installed in compliance with the National Electrical Code.

\section{SYSTEM DESIGN}

The photovoltaic electrical power system includes a $2.4 \mathrm{~kW}$ PV array, a $25.2 \mathrm{kWh}$ battery energy storage system, a charge control system, and an inverter to deliver the dc energy to the load. The system is designed to charge the battery using energy from the PV array. The PV array is mounted on the south facing roof of the residence. The Chandler House is an all-electric, 1500 square foot, three bedroom, single level, block construction hquse, typical of 


\section{DISCLAMIER}

Portions of this docoment may be illegible in electronic image products. Images are produced from the best available origion docoment. 


\section{DISCLAIMER}

This report was prepared as an account of work sponsored by an agency of the United States Government. Neither the United States Government nor any agency thereof, nor any of their employees, makes any warranty, express or implied, or assumes any legal liability or responsibility for the accuracy, completeness, or usefulness of any information, apparatus, product, or process disclosed, or represents that its use would not infringe privately owned rights. Reference herein to any specific commercial product, process, or service by trade name, trademark, manufacturer, or otherwise does not necessarily constitute or imply its endorsement, recommendation, or favoring by the United States Government or any agency thereof. The views and opinions of authors expressed herein do not necessarily state or reflect those of the United States Government or any agency thereof. 
many Phoenix-area tract homes built in the 1980s. The home is occupied, creating a real load for this project. The battery, power center, inverter, other balance of system components, and the control and data acquisition system are located in an equipment room at the rear of the house. The PV-battery energy storage system was sized to deliver electricity solely to the residential load and to eliminate any energy being fed back into the SRP electrical distribution system. This constraint was placed on the system in order to allow the project to focus on system operation and performance and the investigation of economic benefits without having to address net metering or buy-back rate considerations.

\section{SYSTEM OPERATION}

System operation is supervised by a control system developed by SWTDI [2]. The SWTDI-designed control system manages energy delivery from the PV system, energy stored in the battery, and energy delivery to the load. The control system is designed to maximize the economic value of the energy from the PV array. This includes energy directly delivered by the PV array to the load, and stored energy delivered from the battery to the load, delivering both during peak energy-value periods. The control system also minimizes the amount of energy delivered to the residential load outside of the peak period by storing this energy in the battery. The control system is designed to discharge energy stored in the battery through the inverter to the load at a utility-specified three-hour (peak energy demand) period.

Control system operation is illustrated in Figure 1. This figure shows control system operation during a typical July (summer) day and shows the battery bank being charged by the PV array (battery charging), stored solar energy being discharged

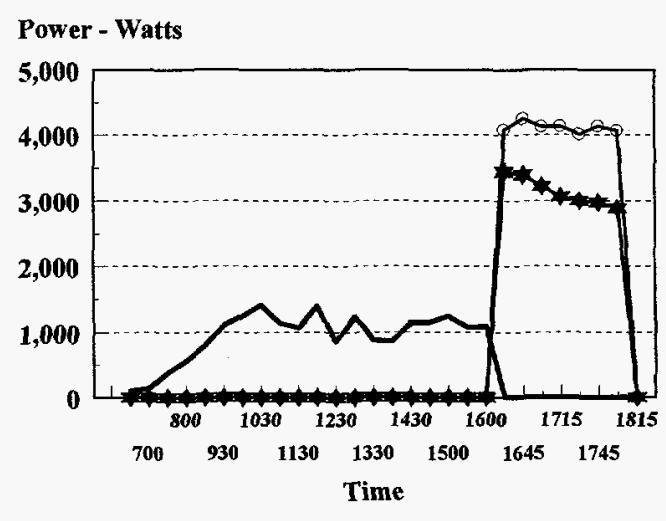

Battery Charging Battery Discharging Power to Load

Figure 1. Control System Operation - Summer Day from the battery bank (battery discharge), and power being dispatched to the residential load. Note the difference between "battery discharge" and "power to load" during the peak hours of $4: 00$ to $6: 00 \mathrm{pm}$. "Battery discharge" is dc current measured out of the battery, and "power to load" is ac energy out of the inverter. The difference is losses in the inverter and dc wiring from the battery to the inverter.

\section{SYSTEM PERFORMANCE}

The system has operated reliably and as designed since its installation, with the exception of minor start-up problems that were associated with another, existing PV system. During September and October 1995, there were two problems which affected system operation. The first was an interface malfunction in a companion PV system located at the host site. This malfunction resulted in both systems being off-line for three days. The second resulted from a communication problem between the modem used to collect data and the data acquisition systems associated with each PV system. This resulted in data being lost from both systems for several days in October. Since these problems were fixed, the system has operated continuously and reliably.

The Sandia-provided data acquisition system shows that, for the period November 1, 1995 though July 1997 , the system dispatched about $4,000 \mathrm{kWh}$ to the residential load. Figure 2 shows the energy ( $\mathrm{kWh}$ ac) dispatched to the residential load for each month during this 21 month period. 
Energy To Load

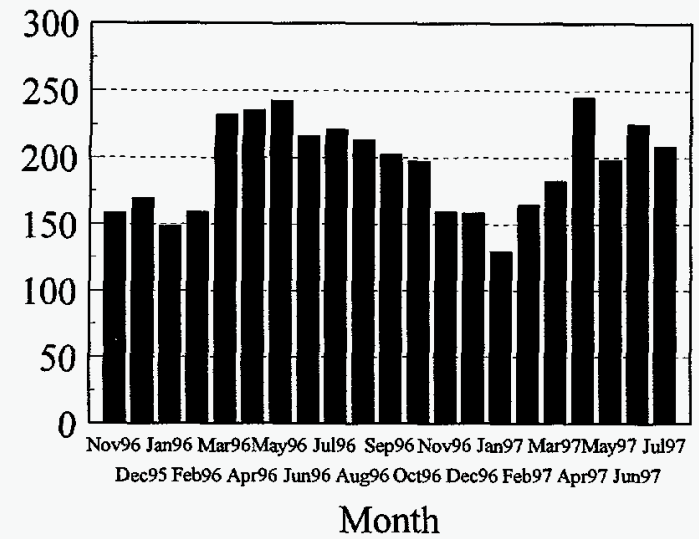

Figure 2. Energy Delivered to Load - kWh

During SRP's winter season (November 1 - April 30), the energy delivered to the load averages about $180 \mathrm{kWh}$ per month while energy delivered to the load during the summer season (May 1 - October 30) averages about $220 \mathrm{kWh}$ per month.

The system's performance and operation proves that the design of this photovoltaic power system with battery energy system is robust and that the control system developed by SWTDI provides for the delivery of stored energy to the residential load during peak demand periods in a reliable and effective manner.

\section{ECONOMIC ANALYSIS}

SRP conducted an analysis to examine the potential economic value of grid-connected PV power systems to their residential customers. The analysis considered the effects of the energy generated from PV power systems on the typical residential customer's annual electric bill in conjunction with SRP'S (E-20) experimental time-of-day residential electric rate with three rate periods or with SRP's standard single period rate schedule (E-26) which is a flat rate of $\$ 0.0899 / \mathrm{kWh}[3]$. SRP's typical residential customer uses $13,700 \mathrm{kWh}$ per year with summer energy use from 1,300 to $1,800 \mathrm{kWh}$ per month. This information was used in conjunction with SRP's rate schedules for a standard residential rate and a three period time-of-day rate [3].

The energy production data for the analysis was based on data collected from the PV power system located at the Chandler Research house. The energy production for the PV-only power system is a calculated value and is based on the actual output of the $2.4 \mathrm{~kW}$ PV array less the assumed losses associated with a $90 \%$ efficient inverter. The PV with battery system data is based on the actual system operational data. Various economic factors were applied to the energy produced and either stored or fed to the load. This information was then analyzed using both SRP's standard flat rate and an experimental time-of-day rate that SRP has developed. The summer time-of-day rate is as follows:

Table 1. E-20 Residential Electric Savings time Service with Three Rate Periods

\begin{tabular}{|l|l|l|}
\hline Rate Period & Time & Energy Charge \\
\hline Off - Peak & $11 \mathrm{PM}-11 \mathrm{AM}$ & $\$ 0.0404 / \mathrm{kWh}$ \\
\hline Shoulder & $\begin{array}{c}11 \mathrm{AM}-2 \mathrm{PM} \\
7 \mathrm{PM}-11 \mathrm{PM}\end{array}$ & $\$ 0.0991 / \mathrm{kWh}$ \\
\hline On Peak & $2 \mathrm{PM}-7 \mathrm{PM}$ & $\$ 0.1720 / \mathrm{kwh}$ \\
\hline
\end{tabular}

The summer flat rate (E-26), which is SRP's standard rate for a home like the Chandler House, and which is used as a comparison in evaluating this project, is $\$ 0.0899 / \mathrm{kWh}$.

The results of this analysis are summarized in Table 2 below. The entry $\$ 1161$ represents the annual bill for the average residential customer with a home similar to the Chandler House. Note that, if this average customer uses the experimental time-ofday rate and does not adjust his energy use patterns to take advantage of that rate, the annual cost of energy increases. This is exactly what a time-of-day rate is designed to do - provide financial incentive to the customer to change energyuse patterns.

Also note that the least-cost option to the customer who does not take advantage of the time-of-day rates by altering energy use patterns, is PV-only using the standard flat rate. There is very little difference between any of the other three options, but they all have higher annual energy costs than PV-only. Why is it that the use of a battery to shift energy to the peak-rate hours results in a higher energy bill than a batteryless system?

There are actually several areas where one could examine the system in detail and find means of improving the PV + battery system economics, but the biggest factor is in the battery losses. A review of the data over the first 14 months of operation shows total system electrical losses (that is, from PV 
output to ac out of the inverter) of roughly $40 \%$. If one assumes that about $10 \%$ of these losses are in the inverter and another $5 \%$ are in wiring and other miscellaneous losses, then that implies $25 \%$ losses in the battery.

Table 2. Economic Comparison with no load management

\begin{tabular}{|c|c|c|c|}
\hline & $\begin{array}{c}\text { Annual } \\
\text { Bill } \\
\text { w/o PV } \\
\text { Power } \\
\text { system or } \\
\text { Energy } \\
\text { Storage }\end{array}$ & $\begin{array}{l}\text { Annual Bill } \\
\text { with PV } \\
\text { Power } \\
\text { System } \\
\text { only }\end{array}$ & $\begin{array}{l}\text { Annual } \\
\text { Bill with } \\
\text { PV } \\
\text { Power } \\
\text { system } \\
\text { with } \\
\text { Energy } \\
\text { Storage }\end{array}$ \\
\hline $\begin{array}{l}\text { Standard } \\
\text { Flat Rate }\end{array}$ & $\$ 1161$ & $\$ 906$ & $\$ 987$ \\
\hline $\begin{array}{l}\text { Experimenta } \\
\text { I Time of } \\
\text { Day Rate }\end{array}$ & $\$ 1213$ & $\$ 975$ & $\$ 980$ \\
\hline
\end{tabular}

\section{Site-Specific Battery Efficiency}

Under ideal conditions of constant $77^{\circ} \mathrm{F}\left(25^{\circ} \mathrm{C}\right)$ temperature and very low charge and discharge rates ( $\mathrm{C} / 100$ or less), the maximum efficiency of flooded lead-acid batteries is $75-80 \%$. With wide temperature variations in the unconditioned battery room $\left(20^{\circ}-100^{\circ} \mathrm{F}\right)$, moderate charge rates $(\mathrm{C} / 15)$, and high discharge rates ( $\mathrm{C} / 9$ and higher), the battery energy efficiencies of $75 \%$ are higher than expected. This indicates that the battery-charging strategy developed by SWTDI was successful in obtaining high efficiencies under less than optimal conditions. This strategy consists of bringing the battery to about $85 \%$ state of charge each day (using PV energy), then discharging the battery during the daily peak. SRP has no peak times on the weekends, so every second weekend the battery is equalized to minimize problems with sulfation and stratification.

\section{CONCLUSIONS}

This project has successfully demonstrated that the hardware exists and functions properly to allow PV energy to be stored during off-peak hours and then dispatched during peak hours. This project also demonstrates that a system operated in the manner of the current Chandler House design can not be justified on economics alone.
There are, however, modifications to system operation that could impact that economic position. As with many other energy conservation projects, one strategy by itself is often inadequate. That is, the shifting of energy from the solar peak to the utility peak needs to be coupled with shifting of energy usage by the customer. Customers can certainly be educated to take advantage of the $4: 1$ ratio in retail energy cost between on-peak and offpeak energy. This, when coupled with energy shifting by battery storage, could result in significant savings to the customer.

In addition, minor changes in energy-storage strategy could have a significant impact. For example, as currently operated, the battery is mostly charged with energy that has a retail value of either about $10 \%$ or $17 \phi / \mathrm{kWh}$ (refer to time-of-day rates in Table 1). Once it is realized that about $40 \%$ of this expensive energy simply supplies losses, it becomes clear that economics are better served by charging the batteries with off-peak utility energy at $4 \phi / \mathrm{kWh}$, and using the PV energy to meet loads or sell to the utility as it is available. This strategy then leads to questions regarding net metering. If the interconnected utility has a net metering policy, then the PV energy passed through to the utility has the full retail value of 10 or $17 \phi / \mathrm{kWh}$. If the utility does not have a net metering policy, then the energy passed through to the utility will only be valued at the utility's avoided cost of around $2-4 \phi / \mathrm{kWh}$. If this is the situation, then the original system operation strategy at Chandler House gives better economics to the customer.

Finally, there is value associated with the fact that this system is capable of providing energy during a utility outage. This value is difficult to quantify, as the value will vary considerably depending on the customer and their needs and perceptions. For example, a customer with electrically-powered medical equipment in their home will probably value this feature higher than one without such critical loads.

Clearly, the basic concept of storing off-peak energy for on-peak use is viable, and has been investigated and practiced for many years with a variety of technologies. The challenge for battery-energy storage with PV systems is to create an economic situation that will both benefit the interconnected utility and encourage utility customers to adopt the 
strategy. Sandia and SRP plan to continue with this project to determine means of increasing the value to the customer of battery energy storage in PV systems.

\section{REFERENCES}

[1] E. Palomino, and J. Wiles. "Salt River Project Residential Photovoltaic-Battery Energy Storage System Project." EPRI Report TC3779-003, July 1997.

[2] E. Palomino, and J. Wiles, "A Control System for Improved Battery Utilization in PV-Powered PeakShaving System", 25th IEEE PVSC, 1996.

[3] SRP Corporate Pricing. "Standard Electric Rate Schedules," May 15, 1996. 